\title{
SOCIAL COMMUNICATION OF ADDEWATANG PUTTA SERENG RITUAL IN BONE REGENCY
}

\author{
Bustan Kadir ${ }^{1}$, Tuti Bahfiarti ${ }^{2}$, Muhammad Farid ${ }^{3}$ \\ 1bustan.kadir@gmail.com, 2tutibahfiarti@yahoo.com, ${ }^{3}$ faridemsil@yahoo.com \\ ${ }^{1,2,3}$ Hasanuddin University
}

\begin{abstract}
The diversity that exists in Indonesia should be one of the reasons why communication is important to be studied, and depth analysed. Diversity will produce harmony when it managed by good communication and understanding. This study analysed social life in the Addewatang Putta Sereng ritual practised by a community in Bone Regency as a form of diversity. Focusing on communication behaviour in the Addewatang Putta Sereng ritual, this study would first (1) analysed religious messages, and subsequently (2) identify social communication in the Addewatang Putta Sereng ritual. This research used a qualitative method by using the ethnographic communication approach. Data were collected through in-depth interviews, observations, and documentation, then analysed using ethnographic data analysis. The results of this study indicated that the implementation of the Addewatang Putta Sereng ritual is a symbol of the belief (ateppekeng) and gratitude (asukkurukeng) of Ujung people towards the figure of Putta Sereng and God Almighty. Social communication in the Addewatang Putta Sereng ritual forms harmonious communication patterns, consisting of resistance and responsive communication practised by community groups that are resistant and conservative to the Addewatang Putta Sereng ritual.
\end{abstract}

Keywords: Social Communication, Religious Message, Ritual, Addewatang, Putta Sereng

\section{INTRODUCTION}

The appearance of the duality expression that looks contradictory in Indonesian beliefs is at least inseparable from two things namely; the existence of ancestral beliefs heritage and the emergence of belief in religious teachings that came later. For instance, A. Kholil (2008) shows one of the habits practiced by the Javanese people to date in the form of Slametan or Kenduri rituals. On the one hand they recognize the truth of the teachings of Islam by practicing what is ordered and forbidden in it, however, on the other hand they also still believe in the tradition of Hindu-Buddhist heritage that existed before.

Knowing the diversity in Indonesia should be the main reason why the communication study very important to analyze and depth study. Well-managed communication will bring understanding between the diversity. Therefore, the duality of expression that looks contradictory in people's beliefs is a social phenomenon that should not be used as a problem that threatens social stability. Exactly the mistakes in interpreting religious messages and fanaticism in beliefs that need to be worried can be the trigger. That is why Anthony Giddens (2006) suggests that in analyzing religious practices, we must understand the various beliefs and rituals found in various human cultures.

The duality phenomenon expression in belief is also commonly found in the Bugis community in Bone Regency, for instance is the village called Ujung Village. The society there carry out a ritual called Addewatang Putta Sereng as part of their ancestral heritage which they must guard and respect. Sociologically, Fifiana Dewi (2017) states that this habit shows a positive value that is able to integrate the 


\section{9 | JURNAL ILMU BUDAYA}

community because the implementation of this ritual shows a variety of social behaviors in the form of social interaction, social solidarity, a system of togetherness in social life, and the meaning of life symbolically. Rais (2015) further revealed that the Ujung people considered the implementation of the Addewatang Putta Sereng ritual to strengthen religious, psychological, and latent social networks.

Social communication in Ujung community becomes very important to be described considering that in addition to groups that accept and carry out this Addewatang ritual, there are also community that are openly identified as those who reject it. Rais (2015) states that there are at least two groups that reject this ritual, namely the followers of the Khalwatiyah order and the pesantren community group. However, both of groups always keeps a tolerant attitude towards the group that runs the ritual. Rais (2015) and Dewi (2017) 's previous research on the Addewatang ritual has provided a basis for this research through the identification of groups that are resistant to the Addewatang ritual. Therefore, in this study would be more focused on the analysis of religious messages and identification of social communication displayed by these groups in the Addewatang Putta Sereng ritual.

\section{CONCEPT AND THEORY Social Communication}

Humans are social beings who actually need communication in socializing. Mulyana (2007) places social communication as one of the functions of communication, where social communication at least implies that communication is important for building self-concept, self-actualization, survival, obtaining happiness, avoiding pressure and tension, through entertaining communication, and foster relationships with others. Cangara (2009) also mentioned that there are two needs that encourage humans to communicate, namely the need to maintain their survival and the need to adapt to their environment. Contextually, social communication is human communication, which means social communication only occurs between humans and fellow humans to create harmonious relationships in life.

\section{Religious Message}

The message in the communication process consists of messages in the verbal and non-verbal form. Verbal messages are all types using the symbols that use one or more words and those are generally deliberately used consciously to connect with others verbally, a verbal code system called language. Non-verbal messages are all signals that are not words. According to Larry A. Samovar and Richard E. Porter in Mulyana (2008) nonverbal communication includes all stimuli (except verbal stimuli) in a communication setting produced by individuals and the use of the environment by individuals, which have the potential message value for the sender or receiver. If related to religious terminology, the message in question is more directed to messages relating to religious teachings universally.

\section{Ritual Bugis Syncretism}

Ritual is a procedure in a ceremony or a sacred act performed by a group of religious people. This is marked by the existence of various elements and components, namely: the time, the place where the ceremony is performed, the tools of the ceremony, and the people who carry out the ceremony (Koentjaraningrat, 1985: 56). The Buginese is one of the tribes in Indonesia which has a diversity of traditions in the form of syncretism rituals. Bahfiarti (2013) revealed that there are 


\section{0 | JURNAL ILMU BUDAYA}

many things in Bugis culture that are expressed through symbols with certain meanings and can only be understood by the Bugis tribe itself.

Pelras (2006) describes that traditional beliefs or termed syncretism in traditional Bugis societies can be classified as esoteric syncretism and practical syncretism. The category of esoteric syncretism is the teachings originating from the early period of islamization, which is spread through mostly oral texts (although there are a few written ones). The practical syncretism does not have a particular conceptual formulation, and it can only be concluded from observations of the rituals carried out by the Bugis.

\section{Theory of Symbolic Interactionism}

The symbolic interactionism theory (symbolic interactionism) began of social science that was built by scientist George Herbert Mead. This theory focuses its attention on the ways that humans use to shape the meaning and structure of society through conversation (Morissan, 2015). This theory had continued by Herbert Blumer who was a student from Mead known as the Chicago school. Blumer in Griffin (2019) states three core principles in symbolic interactionism which include meaning, language, and thinking.

Ralph LaRossa and Donald C. Reitzes in West \& Turner (2008) summarize three main themes consisting of seven basic assumptions of symbolic interactionism theory, namely: first, humans act towards other humans based on the meaning given by others to them ; second, meaning is created in human interaction; third, the meaning is changed through an interpretive process; fourth, individuals develop self-concepts through interactions with others; fifth, self-concept provides important motives for behavior; sixth, people and groups are influenced by cultural and social processes; and seventh, social structure is produced through social interaction.

The theory of symbolic interactionism is influenced by social structures that shape or cause certain behaviors, which then form the symbolization of social interaction (Ahmadi, 2008).

\section{RESEARCH METHODS}

This research is a qualitative study using an ethnographic communication approach. This approach is part of the ethnographic method applied specifically to see communication behavior in a particular culture, not human behavior as a whole as in ethnography in general (Kuswarno, 2008). The communication behavior in question is the action or activity of a person, group, or audience that is seen in the communication process (Effendy, 1989), so that in this study the communication behavior in question is the communication behavior in the Addewatang Putta Sereng ritual procession.

The research was carried out in Bone Regency, precisely in Ujung Village, Dua Boccoe Subdistrict, which is the location where the Addewatang Putta Sereng community and rituals are located. Data were collected using in-depth interview techniques, observations, and documentation. In-depth interviews were conducted with informants who had been determined by purposive sampling technique based on the categories created. The collected data is then analyzed using ethnographic data analysis techniques which include three stages, namely description, analysis, and interpretation.

\section{RESULTS AND DISCUSSION}

Based on in-depth interviews with informants, and observations of everything related to the Addewatang Putta Sereng ritual, plus related reading references, in 


\section{1 | JURNAL ILMU BUDAYA}

Volume 8, Nomor 2, 2020

this part the researcher elaborated on the results of research that answer the problem as follows.

\section{Religious Message Addewatang Putta Sereng Ritual}

The existence of the local Addewatang ritual in Ujung Village proves that the Ujung people are conservative towards their ancestral traditions, which in their view had existed before the emergence of the religion practiced by all Ujung communities, namely Islam. Even as a cultural site, the Ujung village head mentioned that the Addewatang rite existed before the Kingdom of Bone was formed and was classified as a prehistoric site.

The implementation of the Addewatang Putta Sereng ritual is an implementation of religious messages understood by the society for what they contain. The message showed the horizontal relationship between people and vertical relationship connection between the community and God. The Researchers still say "God" because in various interviews conducted by researchers, there was no informant who stated that this ritual was carried out solely for the figure of Putta Sereng, but their intentions remained for God Almighty, which in Bugis language they called Puang Sewwae.

The Addewatang Putta Sereng ritual is a religious tradition that has been transformed into religious institutions for the Ujung's society. These institutions form behavior and then produce symbols in social interaction.

\section{Symbolization of Belief (Ateppekeng)}

Faith is a main element in religious institutions. The implementation of the Addewatang ritual emphasizes that the Ujung society have a strong belief in the figure of Putta Sereng who they consider to be a savior and accident giver in life. The legitimacy of the Putew Sereng Addewatang Sereng ritual was strengthened due to the various evidences of the granting of requests that they believed took place after the ritual implementation, as well as the calamity that they believed took place as a result of Putta Sereng's wrath.

The strong belief makes the Addewatang ritual has become a life cycle for the Ujung's people, because this habit is something that is done repeatedly. Pascal Boyer (1990) called it traditional repetition. According to him, this can happen through two ways, either through intentional (intentional) processes or automatically. Ujung people who carry out this ritual are conservative groups who believe in the Putta Sereng myth, so this makes the practice of syncretism still survive.

The Ujung's society who believed in Putta Sereng always say the phrase "makkatennika lao ri Puang Allah Ta'ala, na umattugengkeng ri Puangta La Putta Sereng" which means "I hold fast to Allah SWT, and pin my hopes on Putta Sereng". This expression becomes a refutation that see their social behavior as a deviation in religion. If likened to the phrase, it puts Putta Sereng between humans and God, so that people believe that it is a link, then for them it takes a very large role from the figure of Putta Sereng. In addition, there is a construction of understanding that says that the figure of Putta Sereng is not dead, but only disappears, and will appear at any time.

\section{Symbolization of Gratitude (Asukkurukeng)}

As a symbol of gratitude, the implementation of the Addewatang ritual is the manifestation of people's gratitude for Putta Sereng's services, thanks statment 


\section{2 | JURNAL ILMU BUDAYA}

to the Ujung's society who were able to enjoy a good life after being freed from the crisis life in the past. Ujung's consider it a blessing (barakka') with its appearance saving lives. Therefore, the offerings of the Addewatang ritual are also referred to as barakka 'by the society in Ujung, even they are willing to scramble to get them.

The Addewatang ritual that is being carried out now is not only showing gratitude for the services of Putta Sereng in the past. The community has assumed that all their achievements or results in life are inseparable from the intervention of Putta Sereng. Thanksgiving events after marriage, child marriage, housewarming, and various other forms of thanksgiving are always coupled with the Addewatang ritual to show the legitimacy of the existence of Putta Sereng who is always present to help people's lives.

The gratitude that is manifested in the Addewatang ritual not only concern these matters, But Gratitude also for the relief from the illness suffered is also one of the reasons for the Ujung society to perform rituals. Because of the understanding that also arises in the community that the disease they suffer is basically the wrath of Putta Sereng, and will recover when he is no longer angry by holding the Addewatang ritual.

\section{Social Communication in Ritual Addewatang Putta Sereng}

The implementation of the Addewatang Putta Sereng ritual in Bone Regency shows social communication behavior in the form of resistance and responsive communication. The existence of these two communication patterns is a manifestation of communication over differences of opinion that arise between conservatives and resistance groups to the ritual of Addewatang Putta Sereng.

As in the theory of symbolic interactionism which states that individuals respond to a symbolic situation, which can be physical (objects) or social objects (human behavior). The Addewatang Putta Sereng ritual as a symbolic situation in the form of social objects is responded by resistance behavior from groups who have different understandings from conservative groups. This gives birth to cognition in conservative groups and subsequently shows the communication response to the resistance group earlier.

\section{Resistance Communication}

Community understanding of a tradition will not always be the same, it may be that in the future there will be different views that are not in line or in other words against the tradition. Especially if the tradition or culture is juxtaposed with certain religious teachings or understandings, of course it will be very difficult to find a meeting point between the two.

Ujung Village has experienced various developments especially in the aspect of education. Access to education for Ujung children became very easy when the establishment of a religious education institution in the form of a pesantren in 2003 ago. This boarding was later named the Al-Ikhlas Ujung Islamic Boarding School, and was founded by a national figure who currently serves as Imam Besar (the high priest) of the Istiqlal Mosque in Jakarta, Prof. Dr. KH. Nasaruddin Umar, MA.

Then the pesantren began to enter the social life of the community and responded to the Ujung community tradition which they considered as the inheritance of their ancestors, including the custom of the community in carrying out the Addewatang ritual. Finally, cognition started in a conservative society that the pesantren was one of the Ujung communities who opposed their habits. 


\section{3 | JURNAL ILMU BUDAY}

The pattern of communication shown that it does not openly justify the Addewatang ritual practiced by the Ujung people. Through educational communication, the pesantren tried to approach Ujung children by providing understanding and education about behaviors that deviate from religious teachings by alluding to the habits of the Ujung people.

The resistance afterwards came from those who generally from Islamic boarding schools or people who had religious background, whether the original Ujung people or people who came from outside Ujung because of certain ties such as marriage ties with the Ujung's. Thus, being in the midst of a community carrying out the Addewatang ritual is a necessity that they cannot avoid.

They still build good relationships through communication with the people who carry out rituals. There are stages in the Addewatang ritual procession that allows the involvement of these parties, for example in the mangobbi tau (invitation) stage for banquets. In this stage, they clearly see the various resistance reactions that they display in the form of communication, both verbal and nonverbal when invited to a banquet, they will look for reasons not to attend

Unlike the case when the invitation is in the form of mabbaca Barzanji (reading the book of Barzanji), they will be happy to attend this section. According to them reading Barzanji does not contradict religious teachings, because the reading contains prayers and salawat to the Prophet Muhammad. Another reaction was also shown by those who were married to an Ujung woman whose family carried out this Addewatang ritual.

Various displays of resistance both verbally and nonverbally are seen from this group. They will try their best not to be involved in the series or stages of the Addewatang ritual. They will do a number of things ranging from looking for reasons not to be at home as long as the ritual procession is not over, or remain at home but remain in the room.

The final form of resistance communicated by these groups is not to eat the sanro-readings or the main dish used as a fattuana in the Addewatang ritual. They will firstly ask the origin of the food served to them, and if any food they identify has a connection with the ritual, then they will not eat it.

The reactions shown by these resistant sides both verbal and nonverbal are solely as their efforts to maintain harmonious relations within the Ujung community. The dominance of nonverbal communication practices displayed by the resistance party serves to avoid various lengthy debates that have the potential to produce dissension, as well as to reinforce the attitude of the resistance parties.

\section{Responsive Communication}

The resistance communication pattern above is dominated by the communication behavior of those who's not accept the Addewatang ritual. This part explained the responsive communication as part of social communication practices in the Addewatang Putta Sereng ritual. This responsive communication is the communication of community groups who carry out rituals as a reaction to the attitude of resistance to the ritual Addewatang.

Basically, the society who carry out the Addewatang ritual have been able to identify those who are resistant to what they are doing. One of the assumptions of the symbolic interactionism theory is that humans act on other humans based on the meanings given by others to them. Resistance behavior was also responded through several communication patterns displayed by the community who carried out the ritual. Starting from the response to the food offerings that are intended for 


\section{4 | JURNAL ILMU BUDAY}

Volume 8, Nomor 2, 2020

Barzanji readers who are considered resistant.

Ujung's peopls who do the celebration will prepare different dishes for the Barzanji readers (readers of the Book of Barzanji), usually the type of food served does not show the element of fattuana in the Addewatang ritual. For example, it does not bring up the four-color sticky rice (sokko fatanrupa) which is a typical dish of the Addewatang ritual. Or the owner of the intent to explain directly openly the food served, that the food served is not the reading of sanro or for the Addewatang ritual.

There is also among the majority of society who make a celebration still serving all types of offerings to the readers of Barzanji and invited guests without explaining anything. For them, as long as there are no questions about the food served, they remain silent and do not give any statement. Likewise, when the celebration owner wants to invite the resistance groups, the invitation they submit is only a meal invitation for family thanksgiving, and does not declare it as a series of Addewatang rituals.

The practice of social communication in the Addewatang ritual is a portrait of the social harmony of the Ujung people. There is on the one hand the people who are still trying to maintain and carry out the Addewatang ritual which is a custom passed down from their ancestors. On the other hand, later groups also emerged who opposed the habit. In the theory of symbolic interactionism, it is explained that the meanings interpreted by individuals can change from time to time, in line with changes in the situation found in social interactions.

\section{CONCLUSION}

The religious message of the Addewatang Putta Sereng ritual in Bone Regency has meaning as a symbol of the belief (ateppekeng) and gratitude (asukkurukeng) of Ujung people towards the existence of the Putta Sereng figure who mediates their requests to God Almighty and savior in their lives.

Social communication of the Addewatang Putta Sereng ritual in Bone Regency forms a pattern of resistance and responsive communication. This resistance communication is verbal and nonverbal communication shown by groups who refuse to carry out this ritual. The responsive communication is the communication shown by conservative groups who carry out rituals against the communication behavior of the resistance groups. This pattern of social communication practiced will produce a harmonious social life in the Ujung communities in particular, and be a reflection of diversity in life in general.

\section{References}

Ahmadi, Dadi. 2008. Interaksi Simbolik: Suatu Pengantar. Mediator Jurnal Komunikasi. 9, (2).

Ariesta, F.W. 2019. Nilai Moral dalam Lirik Dolanan Cublak-Cublak Suweng. Jurnal Ilmu Budaya. 7 (2), 188-192

Bahfiarti, Tuti. 2013. Baju Bodo dalam Perkawinan Adat Bugis. Jurnal Ilmu Komunikasi. 3, (01).

Boyer, Pascal. 1990. Tradition as Truth and Communication: A Cognitif Description of Traditional Discourse. Cambridge University Press, UK.

Cangara, Hafied. 2009. Pengantar Ilmu Komunikasi. PT RajaGrafindo Persada, Jakarta.

Carbaugh, Donal. 2007. Ethnography of Communication. Donal Carbaugh. 4. 10.1002/9781118611463.wbielsi119.

Creswell, John W. 2014. Research Design: Qualitative, Quantitative, and Mixed 


\section{5 | JURNAL ILMU BUDAYA}

Volume 8, Nomor 2, 2020

Methods Approaches (4th Edition). Sage Publications, United Kingdom.

Dewi, Fifiana. 2017. Perilaku Sosial dan Keagamaan Masyarakat Pada Pelaksanaan "Addewatangnge Da Putta Sereng” (Studi Kasus Pada Masyarakat Desa Ujung Kabupaten Bone). Skripsi tidak diterbitkan. Makassar: UIN Alauddin.

Giddens, Anthony. 2005. Sociology (5th Edition). Polity Press, United Kingdom.

Griffin, EM. 2019. A First Look at Communication Theory, Tenth Edition. McGraw Hill Education, New York.

Hasyim, Muhammad, Akhmar, A. Muhammad, Wahyuddin, Kuswarini, Prasuri. 2019. Foreign Tourists' Perceptions of Toraja as a Cultural Site in South Sulawesi, Indonesia. African Journal of Hospitality, Tourism and Leisure. Volume 8 (3), 1-16.

Koentjaningrat. 1985. Beberapa Pokok Antropologi Sosial. Dian Rakyat, Jakarta

Kuswarno, Engkus. 2008. Etnografi Komunikasi: Pengantar dan Contoh Penelitiannya. Widya Padjajaran, Bandung.

Littlejohn, Stephan. W. dan Foss, Karen. A. 2008. Teori Komunikasi, Edisi 9. Terjemahan oleh Muhammad Yusuf Hamda. 2009. Salemba, Jakarta.

Mattulada. 1995. Latoa: Satu Lukisan Analitis Terhadap Antropologi Politik Orang Bugis, Cetakan Kedua. Hasanuddin University Press, Makassar.

Moleong, Lexy J. 2006. Metodologi Penelitian Kualitatif (Cetakan Ke22). PT Remaja Rosdakarya, Bandung.

Monk, Robert C., dkk. 1979. Exploring Religious Meaning. Prentice Hall International Inc, Londong.
Morissan. 2015. Teori Komunikasi: Individu Hingga Massa (cetakan ke3). Prenadamedia Group, Jakarta.

Mulyana, Deddy. 2007. Ilmu Komunikasi: Suatu Pengantar (Cetakan ke-10). PT Remaja Rosdakarya, Bandung.

Mulyana, Deddy. 2018. Metodologi Penelitian Kualitatif: Paradigma Baru Ilmu Komunikasi dan Ilmu Sosial Lainnya. PT Remaja Rosdakarya, Bandung

Pelras, Christian. 1996. Manusia Bugis. Terjemahan oleh Abdul Rahman Abu dkk. 2006. Nalar, Jakarta.

Rawe, Besse Tenri. 2020. Makna dan Nilai Pappaseng Dalam Lontara' Latoa Kajao Laliddong dengan Arummpone: Analisis Hermeneutik. Jurnal Ilmu Budaya. 8 (1), 15-23.

Rustan, Ahmad S. 2018. Pola Komunikasi Orang Bugis: Kompromi antara Islam \& Budaya, Cetakan I. Pustaka Pelajar, Yogyakarta.

Sobur, Alex. 2004. Semiotika Komunikasi. PT Remaja Rosdakarya, Bandung.

Wahyuni. 2013. Perilaku Beragama; Studi Sosiologi Terhadap Asimilasi Agama dan Budaya di Sulawesi Selatan, Cetakan I. Alauddin University Press, Makassar.

West, Richard. and Turner, Lynn H. Introducing Communication Theory: Analysis and Application. McGrawHill, New York.

Zakiah, Kiki. 2008. Penelitian Etnografi Komunikasi: Tipe dan Metode. Mediator Jurnal Komunikasi. 9, (1).

Rais, Muhammad. 2015. Reproduksi Kepentingan dalam Praktik Agama Lokal: Studi Etnohistoris Terhadap Ritual "Addewatang" dalam Masyarakat Ujung-Bone. Disertasi tidak diterbitkan. Makassar: Program Pascasarjana UIN Alauddin. 